\title{
The Mid-Pliocene sea-level conundrum: Glacial isostasy, eustasy and dynamic topography
}

\author{
A. Rovere ${ }^{\mathrm{a}, *}$, M.E. Raymo ${ }^{\mathrm{a}}$, J.X. Mitrovica ${ }^{\mathrm{b}}$, P.J. Hearty ${ }^{\mathrm{c}}$, M.J. O'Leary ${ }^{\mathrm{d}}$, J.D. Inglis ${ }^{\mathrm{e}}$ \\ a Lamont Doherty Earth Observatory, Columbia University, 61 Route 9W, Palisades, NY 10964, USA \\ b Department of Earth and Planetary Sciences, Harvard University, 20 Oxford Street, Cambridge, MA 02138, USA \\ c Department of Environmental Studies, University of North Carolina at Wilmington, Wilmington, NC 28403, USA \\ d Department of Environment and Agriculture, Curtin University, Bentley, Western Australia 6102, Australia \\ e Department of Geological Sciences, University of North Carolina at Chapel Hill, Chapel Hill, NC 27516, United States
}

\section{A R T I C L E I N F O}

\section{Article history:}

Received 31 May 2013

Received in revised form 7 October 2013

Accepted 23 October 2013

Available online $\mathrm{xxxx}$

Editor: J. Lynch-Stieglitz

\section{Keywords:}

Mid-Pliocene sea level

Australia

Republic of South Africa

southeast coast USA

dynamic topography

isostasy

\begin{abstract}
A B S T R A C T
Determining eustatic sea level during the Mid-Pliocene warm period ( $\sim 3.3$ to $2.9 \mathrm{Ma})$ has been a central but elusive goal in the study of past warm climates. Estimates of eustatic sea level based on geologic data span a broad range; variation that we now recognize is due in part to geographically varying post-depositional displacement caused by glacial isostatic adjustment and dynamic topography. In this study, we combine field observations and glacial isostatic adjustment modeling to estimate the dynamic topography signal in three areas that are important to paleo-sea level studies of the Mid-Pliocene warm period (South Africa, West Australia and southeastern United States). We show that dynamic topography played a significant role in the post-depositional displacement of Pliocene, and even younger Pleistocene, shorelines. In this regard, we provide a robust paleo-sea level elevation data set, corrected for glacial isostatic adjustment, that can be used to evaluate predictions from mantle flow models of dynamic topography.
\end{abstract}

(C) 2013 Elsevier B.V. All rights reserved.

\section{Introduction}

The Mid-Pliocene warm period (MPWP), historically defined as the interval between $\sim 3.3$ and $2.9 \mathrm{Ma}$, is widely considered to be an example of a past climate state in equilibrium with $\sim 400$ ppmv atmospheric $\mathrm{CO}_{2}$ levels (Pagani et al., 2009, compare to $\sim 400$ ppmv value as of May 2013; see Fig. S1, Supplementary Materials, for a synopsis). For this reason, this interval of time is an attractive target for climate model validation studies that compare model predictions with climate proxy reconstructions. However, for one key climate variable, polar ice volume in the Pliocene relative to today, little consensus exists in the literature. An accurate estimate of peak eustatic sea level (ESL) at this time would provide insight into both the stability of Greenland and Antarctic ice sheets in a slightly warmer climate and help resolve discrepancies between ice sheet model predictions and data (e.g., Pollard and DeConto, 2009). (In this paper we define ESL change as the geographically uniform change in sea level that would be equal to the volume of meltwater flux into or out of the ocean.) Despite the general agreement on other climatic variables (such as

\footnotetext{
* Corresponding author. Tel.: +1 3474161164 .

E-mail address: rovere@ldeo.columbia.edu (A. Rovere).
}

sea-surface temperature), sea-level estimates for the MPWP vary widely, in part because signals associated with glacial isostatic adjustment (GIA) and dynamic topography (that is, topography supported by convectively-induced viscous stresses in the mantle and associated buoyancy variations in the lithosphere, henceforth "DT") have only recently been taken into account (Raymo et al., 2011; Rowley et al., 2013).

Along several passive margins, Mid- to late-Pliocene shallow water deposits are sometimes found tens of kilometers inland from the present-day shoreline, often at the base of distinctive scarps (Dowsett and Cronin, 1990; James et al., 2006). These scarps were carved, by the relentless erosive action of the sea over the course of dozens of orbitally-paced SL highstands that occurred between the late Miocene and late Pliocene (e.g., Lisiecki and Raymo, 2005). Further, the benthic oxygen isotope record (Lisiecki and Raymo, 2005) suggests that these highstands all peaked approximately the same eustatic value (see Fig. S1, Supplementary Materials, for details). As the ocean eroded steadily inland carving the paleo-sea cliffs, broad coastal terraces also evolved - these coastal plains are now observed to be mantled with younger Pliocene and Pleistocene sediments. At the break in slope, also called the toe, or 'inner margin,' of the scarp, shallow marine deposits date to the late Pliocene, a time correlative with the onset of global cooling associated with the intensification of northern hemisphere glaciation. 


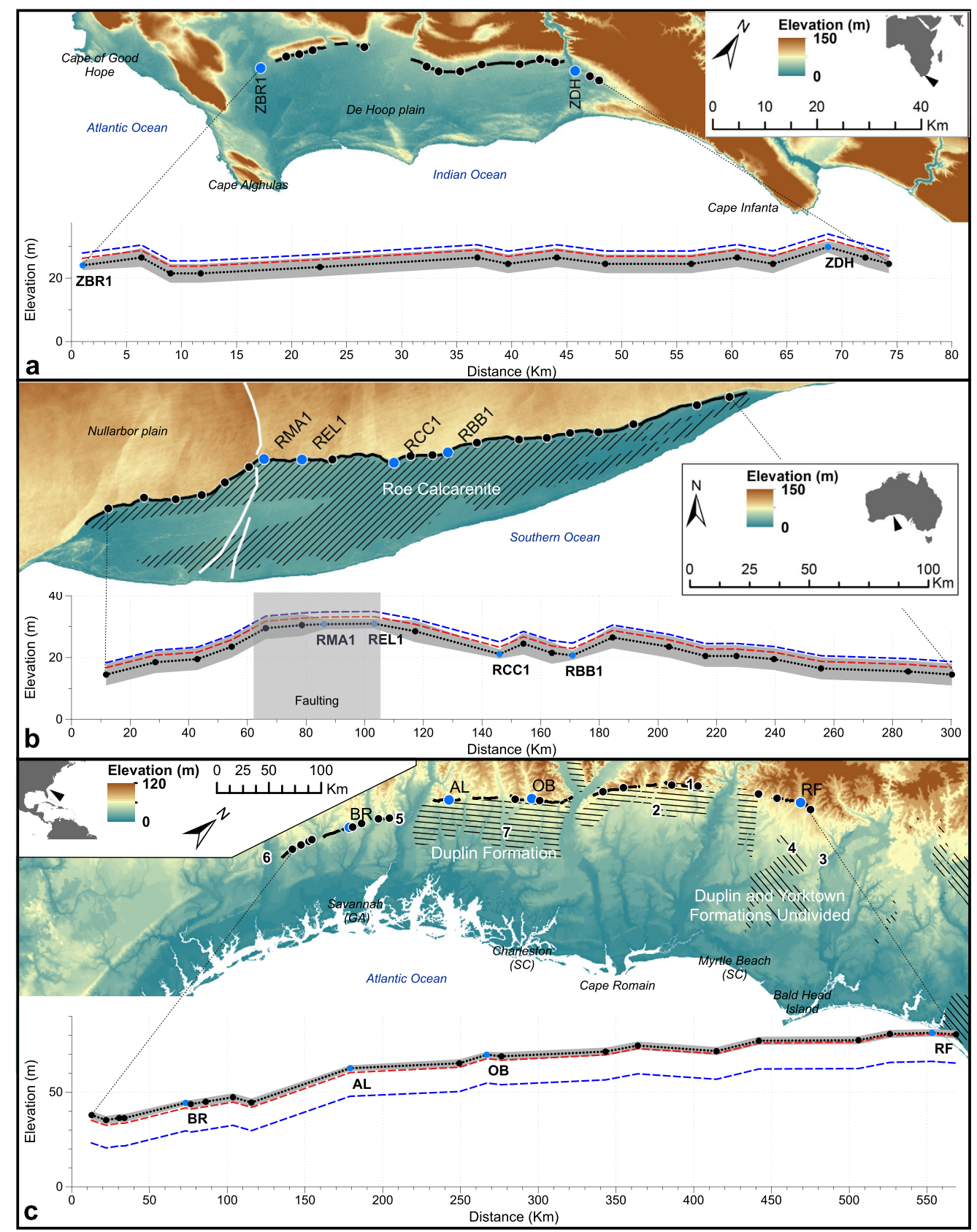

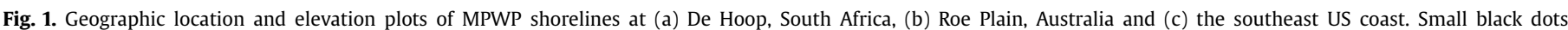

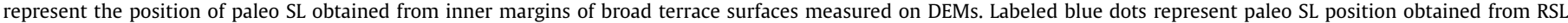

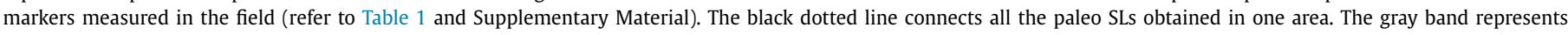

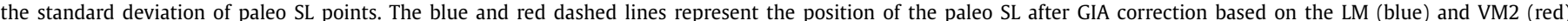

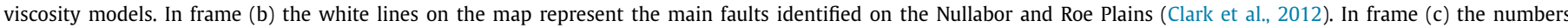

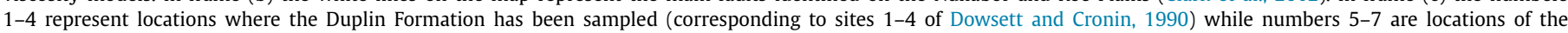

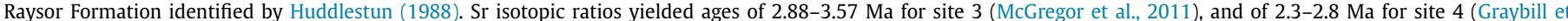

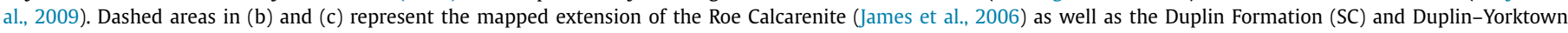

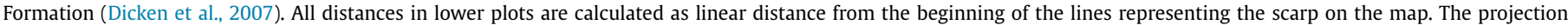

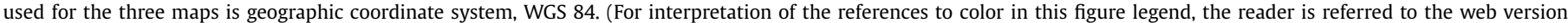
of this article.)

We interpret the slope break as indicative of the former level of the sea just prior to the long-term global cooling trend that began at $\sim 2.9 \mathrm{Ma}$ (see Supplementary Materials for details).

Using digital elevation models (DEMs) and field surveys, we measured the elevation of the slope break of three such scarps, as well as associated SL markers, across hundreds of kilometers in the southern Republic of South Africa, southern Western Australia, and southeastern United States (Fig. 1a, b, c and Table 1). Then, as described herein, we accounted for depositional effects due to GIA using a large set of numerical modeling results.

We then combine GIA-corrected scarp elevations with different eustatic sea-level scenarios to calculate a set of field-based DT predictions for each area, and compare these with previously published DT models. Our ultimate aim is to provide a robust dataset (attached as Supplementary Material) against which future DT model predictions in these three areas can be tested. 
Table 1

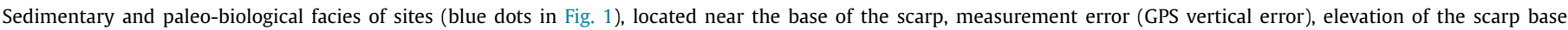
measured near the site and calculation of the paleo SL elevation as represented in Fig. 1 (see Supplementary Materials for details). All measurements are in meters.

\begin{tabular}{|c|c|c|c|c|c|}
\hline Site & Name & $\begin{array}{l}\text { Elevation of } \\
\text { marine facies } \\
\text { (marine limiting) } \\
(\mathrm{m})\end{array}$ & $\begin{array}{l}\text { Scarp } \\
\text { elevation } \\
(\mathrm{m})\end{array}$ & $\begin{array}{l}\text { Paleo SL elevation } \\
\text { (as plotted in } \\
\text { Fig. 1) } \\
\text { (m) }\end{array}$ & Description \\
\hline ZBR1 & $\begin{array}{l}\text { Bredasdorp, } \\
\text { South Africa }\end{array}$ & $21.89 \pm 0.2$ & $22.52 \pm 0.2$ & $24.02 \pm 1.51$ & $\begin{array}{l}\text { Large marine Glycymeris and Ostrea, as described in earlier works on the } \\
\text { Pliocene De Hoop formation }{ }^{16} \text { are found near the base of the scarp. }\end{array}$ \\
\hline ZDH & $\begin{array}{l}\text { De Hoop, } \\
\text { South Africa }\end{array}$ & $26.27 \pm 1$ & $28.32 \pm 1$ & $29.82 \pm 1.8$ & $\begin{array}{l}\text { Coarse, pebbly, fossiliferous calcarenite with large disarticulated Glycymeris } \\
\text { oriented concave down (shoaling) exposed in a near horizontal bench that } \\
\text { regionally defines the top of the terrace surface. }\end{array}$ \\
\hline RMA1 & $\begin{array}{l}\text { Madura Quarry, } \\
\text { Australia }\end{array}$ & $27.64 \pm 0.68$ & $29.3 \pm 0.68$ & $30.8 \pm 1.65$ & $\begin{array}{l}\text { Articulated shells of the venerid bivalve Katelysia, whose modern } \\
\text { representatives live in a sandy littoral seabed }{ }^{17} \text {. }\end{array}$ \\
\hline REL1 & $\begin{array}{l}\text { Elarbilla, } \\
\text { Australia }\end{array}$ & $28.44 \pm 0.28$ & $29.45 \pm 0.28$ & $30.95 \pm 1.53$ & $\begin{array}{l}\text { Fossil shells of Madra rufescens were sampled within a sandy matrix, } \\
\text { typical of a beach environment. As the shells were for most part concave } \\
\text { down, this facies could represent an intertidal to shallow subtidal } \\
\text { paleoenvironment. }\end{array}$ \\
\hline RCC1 & $\begin{array}{l}\text { Carlabeencabba, } \\
\text { Australia }\end{array}$ & $17.50 \pm 0.13$ & $19.62 \pm 0.13$ & $21.12 \pm 1.51$ & $\begin{array}{l}\text { Mactra rufescens shells were sampled within a unit characterized by } \\
\text { borrows of vagile organisms, indicating a marine environment at this site. }\end{array}$ \\
\hline RBB1 & $\begin{array}{l}\text { Boolaboola, } \\
\text { Australia }\end{array}$ & $18.99 \pm 0.17$ & $19.2 \pm 0.17$ & $20.7 \pm 1.51$ & $\begin{array}{l}\text { Marine Glycymeris radians shells were sampled within a unit characterized } \\
\text { by some articulated shells and several randomly oriented ones. }\end{array}$ \\
\hline BR & $\begin{array}{l}\text { Brooklet, GA, } \\
\text { USA }\end{array}$ & $36.3 \pm 2^{\mathrm{a}}$ & $42.82 \pm 0.44$ & $44.32 \pm 1.56$ & \multirow{4}{*}{$\begin{array}{l}\text { The four sites surveyed on the SE coast of the US are locations where the } \\
\text { Pliocene shoreline directly abuts against Miocene or older deposits, } \\
\text { creating a }>5-15 \text { Myr hiatus and subtle, but fairly consistent and } \\
\text { diagnostic geomorphic, sedimentologic, and pedogenic features. Seaward of } \\
\text { the scarp, flat areas (i.e., terraces) are far more extensive than landward of } \\
\text { the scarp. Landward (west) of the scarp, one observes far more hills, } \\
\text { stream valleys, and heavier woodland. The seaward surface sediments are } \\
\text { sandier and pedogenically stained in hues of tan, orange and pink, } \\
\text { compared to the deep-red clay-rich sediments to the west and landward } \\
\text { side of the scarp. }\end{array}$} \\
\hline AL & $\begin{array}{l}\text { Allendale, SC, } \\
\text { USA }\end{array}$ & $27.9 \pm 2^{\mathrm{b}}$ & $61.12 \pm 0.38$ & $62.62 \pm 1.55$ & \\
\hline OB & $\begin{array}{l}\text { Orangeburg, SC, } \\
\text { USA }\end{array}$ & $27.9 \pm 2^{\mathrm{b}}$ & $68.23 \pm 0.38$ & $69.73 \pm 1.55$ & \\
\hline $\mathrm{RF}$ & Raeford, NC, USA & $34.59 \pm 1.11^{\mathrm{c}}$ & $79.80 \pm 1.18$ & $81.30 \pm 1.91$ & \\
\hline
\end{tabular}

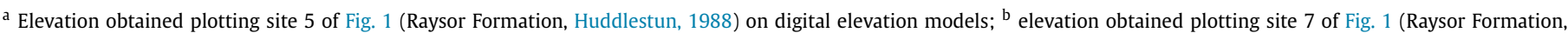

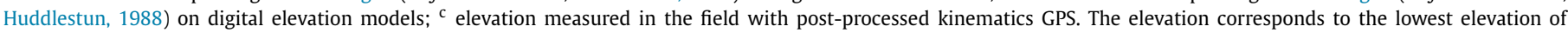

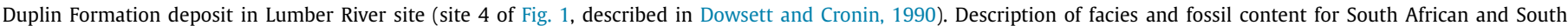
Australia sites is by the authors of this study.

\section{Observed sea-level markers}

The De Hoop coastal plain in the Republic of South Africa (Fig. 1a) has a mean elevation of $\sim 20 \mathrm{~m}$ above modern SL and is delimited inland by a steep inflection of slope (an eroded paleosea cliff), abruptly rising to elevations over $+100 \mathrm{~m}$. Among the units outcropping on the plain, the De Hoopvlei Formation was deposited in a shallow water environment (from intertidal to shallow subtidal, indicating a depth of $0-10 \mathrm{~m}$ ) during the Pliocene (Malan, 1991). Preliminary strontium isotope stratigraphy analysis of an oyster shell from this formation (at site ZBR1) returned an age of $3.56 \pm 1.08 \mathrm{Ma}$, confirming biostratigraphic age estimates.

In southern Western Australia, the Roe Plain is a sub-horizontal terrace located on the southern continental margin, at the head of the Great Australian Bight (Fig. 1b). The $8800 \mathrm{~km}^{2}$ plain is bordered on its northern margin by the Hampton Escarpment, an 80-100 m high paleo-sea cliff that has eroded into early Tertiary marine formations (Lowry, 1970). The Roe Plain is largely an abrasion platform, carved into Cenozoic limestone and thinly-veneered with the Roe Calcarenite, a Pliocene to early Pleistocene shallow subtidal marine assemblage (James and Bone, 2007). In the field, we sampled the Roe Calcarenite near the base of the Hampton Escarpment at multiple locations (Table 1).

The third study area, on the southeastern coastal plain of the US (Fig. 1c), stretches from Georgia (GA) to South Carolina (SC) and North Carolina (NC). Here, numerous studies dating back a half century (Richards, 1963) have identified an almost continuous scarp (Orangeburg Scarp, Ator et al., 2005; Cronin et al., 1984; Huddlestun, 1988; Winker and Howard, 1977) extending from Georgia to Virginia that is interpreted as the geomorphic imprint of the maximum middle-late Pliocene SL ingression (Huddlestun,
1988; Winker and Howard, 1977). In NC and SC the scarp is associated with the Duplin Formation, representing a warm, shallow, normal marine, inner to middle-shelf facies of Mid-Pliocene age (Parnell and Visaggi, 2011), while in northern GA coeval deposits have been associated with the Raysor Formation (Huddlestun, 1988), representing a slightly deeper marine environment than the Duplin (Markewich et al., 1992; Ward et al., 1991). In the field, we measured the elevation of the scarp's base (in most cases coinciding with the inner margin of the Duplin or Raysor Formations, Fig. 1c) with high-accuracy GPS over hundreds of kilometers. The base of the escarpment is particularly well defined at four locations (Fig. 1c). While outcrops of the Duplin and Raysor Formations (Fig. 1c) yield a minimum elevation of the MPWP SL highstand, the toe of the scarp itself is a more accurate paleo SL indicator, representing the position of the former SL to within a few meters (Table 1). At several locations along the scarp, the sandy shoreline facies of the MPWP can be observed lapping landward onto the reddish clayey deposits of Miocene and older ages.

The creation of all three scarps, which collectively traverse more than $1100 \mathrm{~km}$, is consistent with the well-documented process of marine terrace formation during a protracted period of sea-level highstand(s) (e.g. Trenhaile, 2002). The inner angle of the continental-scale scarps is an excellent paleoshoreline indicator. The base of each of these scarps is also associated with Pliocene shallow marine sediments. Of note is that all three paleoshorelines are no longer sub-horizontal; rather, they have all experienced differential uplift and regional deformation. For example, the Orangeburg Scarp is tilted in an N-S direction such that its elevation relative to present sea-level increases from $\sim 35 \mathrm{~m}$ in GA to $\sim 80 \mathrm{~m}$ in NC (Fig. 1c). The Roe Plain has a presentday topography that is $\sim 15 \mathrm{~m}$ higher in its central part relative 

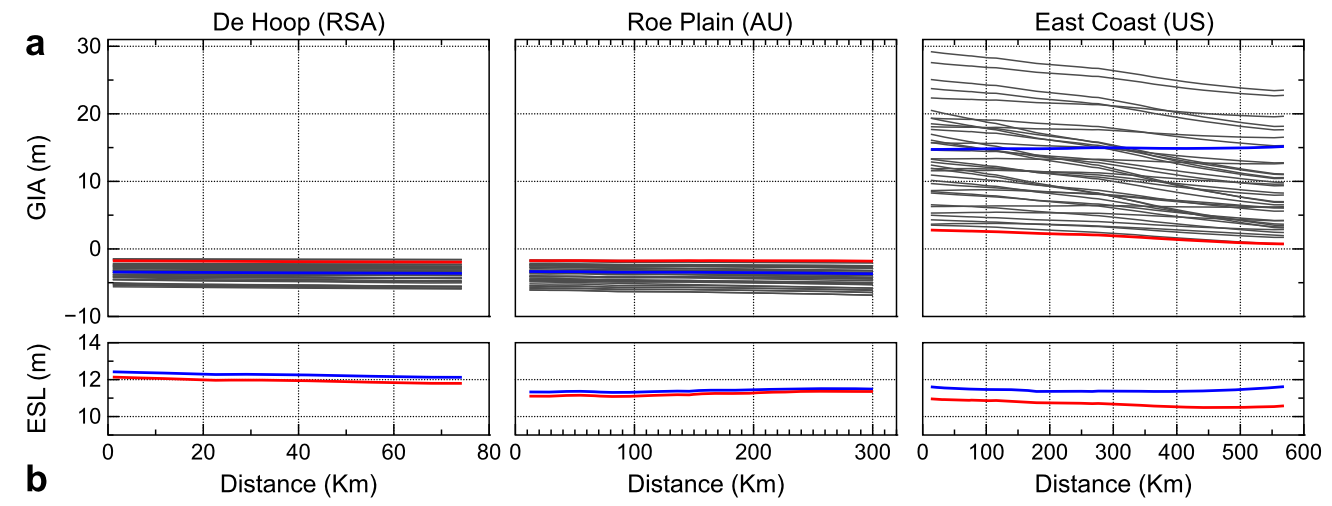

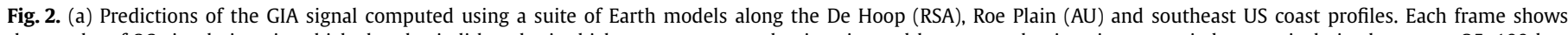

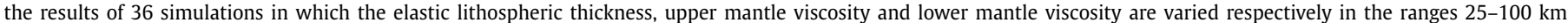

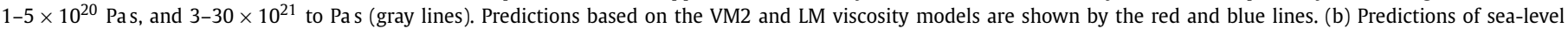

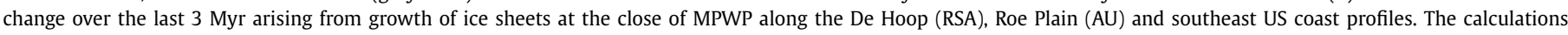

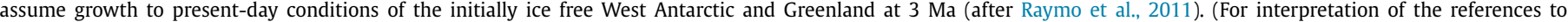
color in this figure legend, the reader is referred to the web version of this article.)

to its edges (Fig. 1b). Finally, the entire De Hoop Plain is currently $\sim 25 \mathrm{~m}$ above present sea level, and it is characterized by relatively small topographic gradients: elevation differences along the scarp are less than $\sim 5 \mathrm{~m}$ (Fig. 1a). Clearly, significant post-depositional processes must have uniquely impacted the elevation of the US and $\mathrm{AU}$ geomorphic features, and possibly the South African scarp as well. Below we discuss these processes and provide constraints on the magnitude of their effects.

\section{Post-depositional effects}

Glacial isostatic adjustment (GIA) in response to changes in ice volume from the MPWP to present-day has led to global scale perturbations in sea level (Raymo et al., 2011). As demonstrated by Raymo et al. (2011) (see their Figs. 2 and 3), this perturbation can be decomposed into two contributions: (1) a residual deflection in sea level associated with incomplete (gravitational, deformational and rotational) adjustment to the late Pleistocene glacial cycles; and (2) a quasi-uniform drop in sea level associated with an increase in ice volumes at the end of the MPWP and isostatic adjustments over the subsequent $3 \mathrm{Ma}$. In the discussion below, we will use the term GIA to refer to the first of these corrections and eustatic sea level (ESL) to refer to the second.

The sea-level signal associated with GIA can be corrected for using numerical simulations. Raymo et al. (2011) provided two such simulations distinguished on the basis of the radial profile of mantle viscosity adopted in the modeling. Viscosity model VM2 (Peltier, 2004) is characterized by a relatively moderate increase in viscosity from the base of the lithosphere to the coremantle-boundary, while the profile LM (Lambeck et al., 1998; Mitrovica and Forte, 2004) has an order of magnitude increase in viscosity across this depth range. In each frame of Fig. 1 we show three profiles along the base of the scarp: the paleo-sea level elevation obtained by survey and DEM data (black line, see Table 1 and Supplementary Materials for details) and the elevation after GIA corrections based on the VM2 (red line) and LM (blue line) viscosity models.

Both the De Hoop coastal plain and the Roe Plain are in the far-field of the late Pleistocene ice sheets, and they are experiencing an ongoing sea-level fall due to the combined effects of ocean syphoning (i.e. a GIA-induced sea-level fall associated with the migration of water toward subsiding bulges at the periphery of ancient ice cover) and continental levering (Mitrovica and Milne, 2002). Accordingly, the observed scarp elevations in these two regions are corrected upwards when the residual GIA signal is removed. The amplitude of the correction is relatively small, $\sim 2 \mathrm{~m}$ for the VM2 simulation and $\sim 5 \mathrm{~m}$ for the LM simulation, and nearly constant along the two profiles (Fig. 1a, b). In contrast to these locations, the US East Coast is on the subsiding peripheral bulge of the last glacial Laurentide ice complex, and a correction for the residual sea-level rise associated with GIA lowers the observed elevation (Fig. 1c). In this case, the amplitude of the correction is a strong function of the adopted viscosity profile. This correction is $\sim 15 \mathrm{~m}$ for the LM simulation and it varies from 0-5 $\mathrm{m}$ for the VM2 model run. The main conclusion from these results is that GIA cannot explain the observed geographic trends in the topography of the three scarps.

Considering only the VM2 and LM models does not provide a rigorous estimate of the uncertainty in the GIA contributions to the profiles in Fig. 1. To quantify this uncertainty we have repeated our GIA simulations using a suite of Earth models distinguished on the basis of the elastic lithospheric thickness $(L T)$ and the (assumed constant) viscosities of the upper $\left(v_{\mathrm{um}}\right)$ and lower $\left(v_{\mathrm{lm}}\right)$ mantle, where the boundary between the latter two regions is taken to be $670 \mathrm{~km}$ depth. In Fig. 2a we show GIA predictions along the three profiles in Fig. 1, computed by varying these parameters in the range: $25 \mathrm{~km} \leqslant L T \leqslant 100 \mathrm{~km} ; 1 \times 10^{20}$ Pa s $\leqslant \nu_{\text {um }} \leqslant 5 \times 10^{20}$ Pa s; and $3 \times 10^{21}$ Pas $\leqslant v_{\text {um }} \leqslant 3 \times 10^{22}$ Pas. These ranges encompass published inferences over the last decade based on a wide suite of GIA data sets. Consistent with the results in Fig. 1, the predictions for the De Hoop and Roe Plain profiles are characterized by a relatively moderate sensitivity to the adopted Earth model. Specifically, the GIA predictions in these regions vary by $\sim 5 \mathrm{~m}$ over the full suite of simulations. In contrast, the sensitivity is much higher along the southeastern coast of the US, where GIA predictions vary over a range of $\sim 30 \mathrm{~m}$ (see also Raymo et al., 2011). It is noteworthy that the VM2 viscosity model, which is close to the lower bound used in this sensitivity study, and also the lower bound of values cited in the literature, yields corrections of $\sim 1-2 \mathrm{~m}$ or less for all three profiles. In contrast, the profile LM yields GIA predictions near the mean value of the full suite of calculations.

Next, we turn to the signal in the present-day elevation of the scarps associated with the increase in ice volumes at the close of the MPWP, i.e., ESL as defined above. As discussed by Raymo et al (2011), this signal would have relaxed, nearly everywhere, to close to a eustatic signal in the $3 \mathrm{Ma}$ subsequent to the base change in sea level. However, minor departures from a globally uniform signal arise because the Earth has an elastic lithosphere, which prevents perfect isostatic adjustment in response to the loading of polar regions, and unloading of the ocean, as ice sheet mass increased on Greenland and West Antarctica at the end of the MPWP. 
This departure can be large (tens of meters) close to the polar ice sheets but smaller (only a few meters) at far-field coastal sites (see Figs. 2b and 3b in Raymo et al., 2011).

There is a second, subtler effect that also contributes to the present-day signal associated with the change in ice volume at the end of the MPWP. At $3 \mathrm{Ma}$, the crust under the West Antarctica would have had a significantly higher elevation than the presentday bedrock elevation since the latter is depressed by the current WAIS.

Thus, a prediction of sea-level change since 3 Ma requires knowledge of the topography field local to the ice sheets at the onset of the loading. While this topography is initially unknown, it can be computed by iteratively improving a first guess to the topography until the full 3 Myr time history of sea-level changes leads to a present-day topography field (e.g., under the WAIS) that matches the observed (Raymo et al., 2011). An important implication of this issue is that the predicted initial topography - in particular within the marine-settings that became covered with ice at the end of the MPWP - is dependent on the adopted GIA model. Therefore, the amount of water displaced by the growth of marinebased ice, which will impact the predicted sea-level change, will be dependent on the GIA model.

As an illustration of these two effects (elastic lithosphere, West Antarctica bedrock elevation), we have computed, using both the VM2 and LM Earth models, the present-day perturbation in the elevation of the three scarp profiles associated with the specific scenario of ice sheet growth at the end of the MPWP considered by Raymo et al. (2011) (Fig. 2b). Their scenario assumed glaciation of both the West Antarctic and Greenland Ice Sheets, both initially ice free, at the end of the MPWP. We find that the predicted signal along the three scarps ranges around 11-12 m (Fig. 2b). While there is a geographic variability in the signals, as well as a dependence on the adopted Earth model, these are both relatively small. This justifies our use of the term "eustatic sea level" (ESL) in describing the present-day signal associated with ice sheet growth at the end of the MPWP.

Finally, we turn to the potential contamination of the presentday scarp elevations by the so-called dynamic topography (Mitrovica et al., 1989; Gurnis, 1990; Moucha and Forte, 2011). All three coastal plains are on "passive" continental margins and they are, therefore, not subject to significant plate boundary processes. However, over the last decade there has been growing appreciation that convection in the Earth's mantle, the underlying driving force for plate tectonics, can produce significant vertical deflections of the crust at all locations on the Earth's surface (Moucha and Forte, 2011; Moucha et al., 2008; Müller et al., 2008; Conrad and Husson, 2009; Rowley et al., 2013) and thus, on time scales relevant to our study, no such thing as a passive margin may exist (Moucha et al., 2008). These deflections, whether they occur in the interior or at boundaries of plates, are termed dynamic topography (Mitrovica et al., 1989). Unfortunately, numerical predictions of dynamic topography by independent groups show significant discrepancies in amplitude and, in some regions, disagreement in sign (i.e. subsidence vs uplift). As an example of note to the present study, backward convection simulations by Rowley and colleagues (Rowley et al., 2013) predict uplift (and sea-level fall) along the US East Coast over the last 3 Ma driven by upwelling flow beneath this region. In contrast, Müller et al. (2008) predict subsidence of the crust (and sea-level rise) in response to the descent of an ancient slab that is now located at mid-mantle depths below the US East Coast. In a general sense, disagreement between the various groups active in DT modeling arises from varying assumptions with regards to mantle viscosity, density heterogeneity (i.e., buoyancy), and the treatment of coupling between mantle convective flow and plate motions. The relative accuracy of the published predictions can be assessed, at least in a regional sense,
Table 2

Scenarios for peak eustatic sea level during the Mid-Pliocene warm interval.

\begin{tabular}{|c|c|}
\hline $\begin{array}{l}\text { Eustatic SL } \\
(\mathrm{m})\end{array}$ & Configuration of ice sheets \\
\hline 0 & $\begin{array}{l}\text { MPWP SL equal to modern, an unlikely scenario given the } \\
\text { widespread geologic evidence for higher global temperatures } \\
\left(2-3^{\circ} \mathrm{C} \text { higher than modern), a forested high Arctic (Tedford and }\right. \\
\text { Harington, 2003), higher atmospheric } \mathrm{CO}_{2} \text { concentrations } \\
\text { (Fedorov et al., 2013), and ice sheet modeling results (Pollard } \\
\text { and DeConto, 2009). }\end{array}$ \\
\hline 14 & $\begin{array}{l}\text { GIS and WAIS deglaciated. No EAIS melting relative to } \\
\text { present-day volume. This is hypothetical scenario assumed in } \\
\text { the recent ice model/isostasy simulations of Raymo et al., } 2011 .\end{array}$ \\
\hline 22 & $\begin{array}{l}\text { GIS and WAIS deglaciated, plus } \sim 8 \mathrm{~m} \text { eustatic sea-level } \\
\text { equivalent ice loss from EAIS. This scenario is based on the } \\
\text { Miller et al., } 2012 \text { study which proposed that it is likely ( } 68 \% \\
\text { confidence interval) that MPWP peak sea level was } 22 \pm 5 \mathrm{~m} \\
\text { above modern. }\end{array}$ \\
\hline 30 & $\begin{array}{l}\text { GIS and WAIS deglaciated and large portions ( } ~ 30 \%) \text { of the EAIS } \\
\text { melted. This scenario approaches some of the highest geological } \\
\text { estimates of Pliocene sea level (Dowsett and Cronin, 1990). }\end{array}$ \\
\hline
\end{tabular}

by comparing the predicted geographic variability in the DT with the geological record (Rowley et al., 2013).

Given the current uncertainty in the DT signal, our philosophy in the next section will be to use the bounds on the GIA signal shown in Fig. $2 a$ to correct the observed scarp elevations for GIA, with an appropriate propagation of uncertainties, thus allowing us to infer DT rates for our sites starting from observed sea-level markers. Also, since the eustatic sea-level correction to the observed scarp elevations is unknown, we consider three scenarios that have been discussed in the literature (Table 2) as well as an additional $(E S L=0)$ scenario. These various corrections, applied to the profiles in Fig. 1, yield estimates for DT that represent physical targets for, and set observational limits on, future efforts to constrain DT using geophysical models of mantle flow.

\section{Estimating dynamic topography}

In this section we estimate the post-MPWP rate of change of DT using the following formula:

$\mathrm{DT}_{\text {rate }}=(\mathrm{OSL}-\mathrm{GIA}-\mathrm{ESL}) / 3 \mathrm{Myr}$

In this formula, observed sea level (OSL) corresponds to the elevation of the paleo SL obtained from the present-day elevation of the ancient SL marker measured in the field or in DEMs (i.e. elevation at the toe of the scarp). This value has an uncertainty related to both the relationship of the geological marker to actual paleo SL and to measurement errors in the determination of the elevation (see Supplementary Material for details). GIA refers to the correction for glacial isostatic adjustment. In this regard, we adopt the average of the 36 model runs shown in Fig. 2a, with an uncertainty given by the standard deviation of these simulations. The ESL for the MPWP remains poorly constrained, and we thus adopt four different scenarios summarized in Table 2. For each scenario, we computed the present-day perturbation in the elevation of the three scarp profiles using both the VM2 and LM models (e.g., Fig. $2 \mathrm{~b}$ for the $14 \mathrm{~m}$ scenario). The ESL correction appearing in Eq. (1) is the average of the LM and VM2 model outputs and their difference is used as a measure of the uncertainty in the ESL correction for each scenario. Our derived estimates of the DT rate along the three profiles based on Eq. (1) are shown in Fig. 3.

Independent of the adopted ESL scenario, De Hoop is the only site that does not show significant variations in the estimated DT rate along the surveyed profile. Numerical models of DT in this region are discrepant (Conrad and Gurnis, 2003; Moucha et al., 2008; 


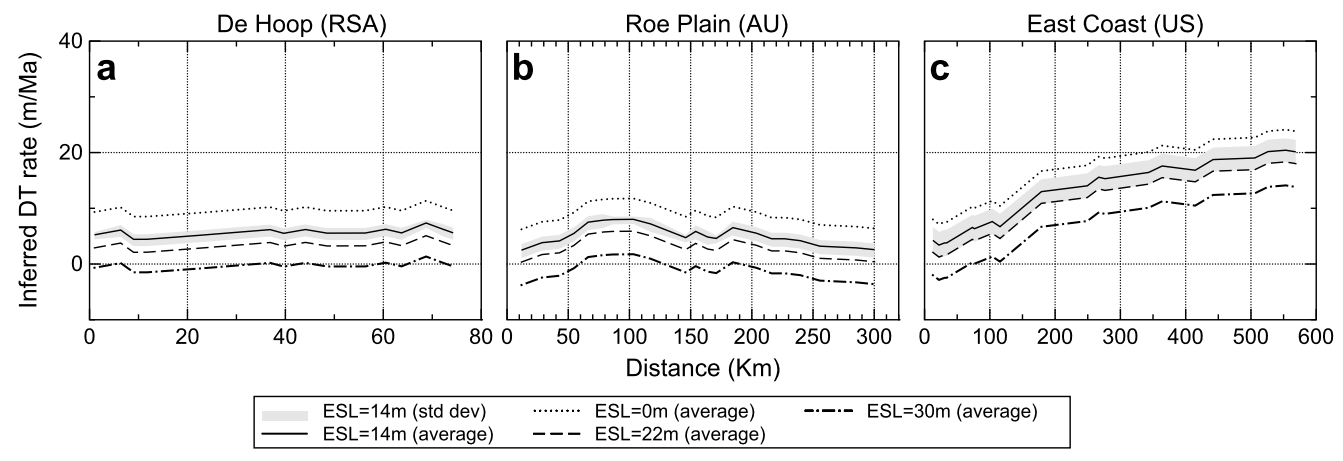

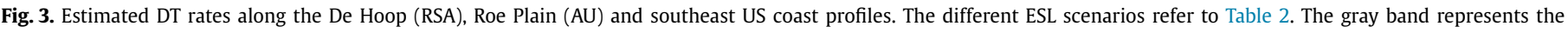
estimated SD for the case ESL $=14 \mathrm{~m}$. All the other cases have error bars of similar amplitude (see Supplementary Materials for details).

Spasojević and Gurnis, 2012), but they are thus suggestive of relative tectonic stability. This conclusion is supported by cosmogenic $\left({ }^{10} \mathrm{Be},{ }^{26} \mathrm{Al}\right)$ burial dating of the Pliocene and Pleistocene age Sunday River terraces on the southern coastal plain of South Africa, located at the eastern edge of the De Hoop profile (Erlanger, 2010). This analysis has been used (Roberts et al., 2012) to infer an uplift rate since $4 \mathrm{Ma}$ of $6 \pm 3 \mathrm{~m} \mathrm{Ma}^{-1}$, an estimate that favors the ESL scenario of $14 \mathrm{~m}$. The high end of their uplift rate would imply an ESL contribution close to 0 , while the low end suggests $\mathrm{ESL}=\sim 22 \mathrm{~m}$.

In contrast, the DT trends for the Roe Plain (Fig. 3b) show significant departures from uniform uplift (Fig. 3b). Moreover, depending on the ESL scenario adopted, the estimates suggest that uplift, subsidence, or a combination of both could have occurred along the profile. Sandiford (2007) (based on the elevation of the early and middle Miocene shorelines of the Nullarbor Plain) inferred that the southern margin of Australia underwent DT-driven uplift at a rate of $10-15 \mathrm{~m} \mathrm{Ma}^{-1}$ during the time window 15-5 Ma. This rate is above the upper bound of the values in Fig. 3b, suggesting that either: (1) the estimate in Sandiford (2007) is too high; (2) uplift rates decreased substantially after $5 \mathrm{Ma}$; or (3) Pliocene ESL highstands were $\sim 0 \mathrm{~m}$, the same as today. In contrast, other modeling studies have suggested that the southern part of the Australian continent has undergone subsidence since 60-70 Ma (Heine et al., 2010; Spasojević and Gurnis, 2012) at a rate of $3 \mathrm{~m} \mathrm{Ma}^{-1}$, and argue that this rate has not changed markedly since $15 \mathrm{Ma}$. This value lies at the lowest end of DT predictions calculated in this study, specifically those based on the ESL $=30 \mathrm{~m}$ scenario.

It is worth noting that in the center of the Nullabor Plain, the large area north of the Roe Plain where Miocene near-shore deposits outcrop, uplift rates of $\sim 1-3 \mathrm{~m} \mathrm{Ma}^{-1}$ have been associated with a fault system, with the upthrown block on the west (Clark et al., 2012), that extends into the central part of the Roe Plain (near Madura, or site RMA1 on Fig. 1). The presence of this fault system is consistent with DT-induced crustal uplift in this central region, and thus may also serve as a constraint on the scenarios in Fig. $3 \mathrm{~b}$.

Finally, along the southeast coast of the US, our estimated DT rates show a significant north-south trend with rates that average, depending on the ESL scenario, from -2 to $+8 \mathrm{~m} \mathrm{Ma}^{-1}$ in GA and 14 to $24 \mathrm{~m} \mathrm{Ma}^{-1}$ in NC (Fig. 3c). The rates calculated for the SC-NC border (13 to $23 \mathrm{~m} \mathrm{Ma}^{-1}, \sim 500 \mathrm{~km}$ from the origin in Fig. 3c) are in accord with the upper end of the estimate given by Soller (1988) (4.6 to $21.3 \mathrm{~m} \mathrm{Ma}^{-1}$ ) on the basis of Pliocene and Pleistocene river terraces linked to marine shorelines in the Cape Fear Arch (southeastern NC). Our average estimates of DT all are consistent with numerical simulations (Moucha et al., 2008; Rowley et al., 2013) which predict a broad zone of uplift (and sea-level fall) along the US East Coast since $3 \mathrm{Ma}$, but inconsistent with other simulations (Müller et al., 2008) that predict subsidence along this entire coast over this time period.

\section{Final remarks}

Our GIA-corrected elevations of geological SL markers dated to $3 \mathrm{Ma}$ indicate that DT has likely produced tens of meters of vertical displacement since these shorelines formed. However, while "there is no such thing as a stable continental platform" (Moucha et al., 2008) over this time period, our analysis suggests some regions have been significantly more stable than others since the Mid-Pliocene.

The southern tip of the African continent serves as one example of such a tectonically stable region and it has the added benefit of being relatively insensitive to uncertainties in the correction for GIA. We conclude that it may be a key area for obtaining reliable estimates of ESL (and ice volumes) at the end of the MidPliocene warm period. In this region, more field observations of Mid-Pliocene sea levels are necessary to allow for a comparison with DT models at a broader spatial scale. Independent observations of Pleistocene sea levels (e.g. MIS 5, MIS 11, MIS 31, for which eustatic sea level is better constrained) would help in establishing a long-term crustal uplift curve.

Data from the Roe Plain may also provide reliable estimates of ancient ice volumes, however more comprehensive constraints on faulting in the region, and its relationship to adjacent areas of the plain and to older shorelines along the Nullarbor plain, are needed.

Along the southeast coast of the US, our data suggest that DT has caused $\sim 55 \mathrm{~m}$ of $\mathrm{N}-\mathrm{S}$ tilting of Pliocene shorelines. The area is also subject to significant sea-level changes due to GIA. A collaborative effort between mantle dynamicists, glacial modelers and the geologists working on ancient sea-level records is needed to generate robust estimates of ESL at the end of the MPWP based on SL markers from this region. It is also worth noting that the tilting evident in (GIA-corrected) results in Fig. 3c, if it is assumed to be constant since $3 \mathrm{Ma}$, should also be discernable in the elevation of GIA-corrected shorelines dated to the last interglacial (MIS 5e), provided that sufficiently accurate sea-level markers are preserved and that suitably precise geodetic measurements of elevation and GIA corrections (Potter and Lambeck, 2003; Raymo et al., 2011) are adopted. As an example, an MIS 5e shoreline at the northern edge of our transect would have been displaced by 1.7 to $3 \mathrm{~m}$ by DT since $125 \mathrm{ka}$, while the same shoreline in Georgia would have been displaced -0.25 to $1 \mathrm{~m}$ as a result of DT. Thus, DT can, in some regions, contribute significantly to the post-depositional uplift or subsidence of observed late Pleistocene sea levels.

Finally, the power of the approach outlined here is that only one ESL scenario can ultimately be correct. If a presumed eustatic sea-level history is derived at one location, a consistent relationship to observed geologic field evidence and dynamic topography models should, with enough data, emerge globally. From the data discussed above we might infer that a Pliocene ESL $<20 \mathrm{~m}$ is the 
most consistent with data. However, a concerted effort to merge a larger body of geologic field data with ever more sophisticated mantle dynamic models will ultimately provide a robust estimate of polar ice sheet stability in the slightly warmer MPWP world.

\section{Acknowledgements}

The authors acknowledge NSF grant OCE-1202632 'PLIOMAX.' A.R. also acknowledges INQUA project 1203. J.X.M. was additionally funded by Harvard University and the Canadian Institute for Advanced Research. This study was motivated by discussions at the workshops of PALSEA, a PAGES/INQUA/WUN working group. The authors thank D. Roberts (Council for Geosciences, RSA), Eugene Bergh (Natural History Department Iziko South African Museum), and M. Robinson (USGS) for insights and assistance with the South African and Western Australian field expeditions. Research along the East Coast of the US was greatly enriched through extensive discussions with R. Portell (UFMNH), W. Doar and R. Willoughby (SCGS), R. Berquist (VA), and R. Lockwood (C William and Mary). The authors thank F.J. Pazzaglia (Lehigh University, PA) and an anonymous reviewer for their constructive comments.

\section{Appendix A. Supplementary material}

Supplementary material related to this article can be found online at http://dx.doi.org/10.1016/j.epsl.2013.10.030.

\section{References}

Ator, S.W., Denver, J.M., Krantz, D.E., Newell, W.L., 2005. A surficial hydrogeologic framework for the Mid-Atlantic Coastal Plain. U.S. Geological Survey Professional paper (No. 1680)

Clark, D., McPherson, A., Van Dissen, R., 2012. Long-term behaviour of Australian stable continental region (SCR) faults. Tectonophysics 566-567, 1-30.

Conrad, C.P., Gurnis, M., 2003. Seismic tomography, surface uplift, and the breakup of Gondwanaland: Integrating mantle convection backwards in time. Geochem. Geophys. Geosyst. 4, 1031.

Conrad, C.P., Husson, L., 2009. Influence of dynamic topography on sea level and its rate of change. Lithosphere 1, 110-120.

Cronin, T.M., Bybell, L.M., Poore, R.Z., Blackwelder, B.W., Liddicoat, J.C., Hazel, J.E., 1984. Age and correlation of emerged Pliocene and Pleistocene deposits, US Atlantic Coastal Plain. Palaeogeogr. Palaeoclimatol. Palaeoecol. 47, 21-51.

Dicken, C.L., Nicholson, S.W., Horton, J.D., Foose, M.P., Mueller, J.A.L., 2007. Preliminary integrated geologic map databases for the United States. Alabama, Florida, Georgia, Mississippi, North Carolina, and South Carolina. U.S. Geological Survey Open-File Report (No. 2005-1323, Updated 2007), http:// pubs.usgs.gov/of/2005/1323/.

Dowsett, H.J., Cronin, T.M., 1990. High eustatic sea level during the middle Pliocene: Evidence from the southeastern US Atlantic Coastal Plain. Geology 18, 435-438.

Erlanger, E.D., 2010. Rock uplift, erosion, and tectonic uplift of South Africa determined with cosmogenic aluminum-26 and beryllium-10. Purdue University.

Fedorov, A.V., Brierley, C.M., Lawrence, K.T., Liu, Z., Dekens, P.S., Ravelo, A.C., 2013. Patterns and mechanisms of early Pliocene warmth. Nature 496, 43-49.

Graybill, E.A., Harris, P.T., Kelley, P., Dietl, G., 2009. Age of the Duplin and Waccamaw formations, Cape Fear River basin, North Carolina. In: GSA Southeastern Section - 58th Annual Meeting.

Gurnis, M., 1990. Bounds on global dynamic topography from Phanerozoic flooding of continental platforms. Nature 344 (6268), 754-756.

Heine, C., Müller, R.D., Steinberger, B., DiCaprio, L., 2010. Integrating deep Earth dynamics in paleogeographic reconstructions of Australia. Tectonophysics 483, 135-150.

Huddlestun, P.F., 1988. A revision of the lithostratigraphic units of the coastal plain of Georgia: the Miocene through Holocene. Georgia Geol. Surv. Bull. 104.

James, N.P., Bone, Y., 2007. A late Pliocene-early Pleistocene, inner-shelf, subtropical, seagrass-dominated carbonate: roe calcarenite, great Australian bight, western Australia. Palaios 22, 343-359.

James, N.P., Bone, Y., Carter, R.M., Murray-Wallace, C.V., 2006. Origin of the Late Neogene Roe Plains and their calcarenite veneer: implications for sedimentology and tectonics in the Great Australian Bight. Aust. J. Earth Sci. 53, 407-419.
Lambeck, K., Smither, C., Johnston, P., 1998. Sea-level change, glacial rebound and mantle viscosity for northern Europe. Geophys. J. Int. 134, 102-144.

Lisiecki, L.E., Raymo, M.E., 2005. A Pliocene-Pleistocene stack of 57 globally distributed benthic $\delta 180$ records. Paleoceanography 20 .

Lowry, D.C., 1970. Geology of the Western Australian Part of the Eucla Basin. Geological Survey of Western Australia, Perth.

Malan, J.A., 1991. Lithostratigraphy of the De Hoopvlei Formation (Bredasdorp Group). Dept. of Mineral and Energy Affairs, Geological Survey, Pretoria.

Markewich, H.W., Hacke, C.M., Huddlestun, P.F., 1992. Emergent Pliocene and Pleistocene sediments of southeastern Georgia: an anomalous, fossil-poor, clastic section. In: Flectcher III, C.H., Wehmiller, J.F. (Eds.), Quaternary Coasts of the United States: Marine and Lacustrine Systems, pp. 173-189. SEPM Special Publication, vol. 48.

McGregor, D.A., Harris, W.B., Dietl, G.P., Kelley, P., 2011. Strontium isotopic dating of the Waccamaw formation at Acme, NC, and the Duplin formation at Tar Heel, NC: a Plio-Pleistocene research progress report. In: GSA Southeastern Section 60th Annual Meeting.

Miller, K.G., Wright, J.D., Browning, J.V., Kulpecz, A., Kominz, M., Naish, T.R., Cramer, B.S., Rosenthal, Y., Peltier, W.R., Sosdian, S., 2012. High tide of the warm Pliocene: Implications of global sea level for Antarctic deglaciation. Geology 40, 407-410.

Mitrovica, J.X., Forte, A.M., 2004. A new inference of mantle viscosity based upon joint inversion of convection and glacial isostatic adjustment data. Earth Planet. Sci. Lett. 225, 177-189.

Mitrovica, J.X., Milne, G.A., 2002. On the origin of late Holocene sea-level highstands within equatorial ocean basins. Quat. Sci. Rev. 21, 2179-2190.

Mitrovica, J.X., Beaumont, C., Jarvis, G.T., 1989. Tilting of continental interiors by the dynamical effects of subduction. Tectonics 8, 1079-1094.

Moucha, R., Forte, A.M., 2011. Changes in African topography driven by mantle convection. Nat. Geosci. 4, 707-712.

Moucha, R., Forte, A.M., Rowley, D.B., Mitrovica, J.X., Simmons, N.A., Grand, S.P., 2008. Dynamic topography and long-term sea-level variations: There is no such thing as a stable continental platform. Geology 271, 101-108.

Müller, R.D., Sdrolias, M., Gaina, C., Steinberger, B., Heine, C., 2008. Long-term sealevel fluctuations driven by ocean basin dynamics. Science 319, 1357-1362.

Pagani, M., Liu, Z., LaRiviere, J., Ravelo, A.C., 2009. High Earth-system climate sensitivity determined from Pliocene carbon dioxide concentrations. Nat. Geosci. 3, 27-30.

Parnell, B.A., Visaggi, C.C., 2011. Inferring Plio-Pleistocene paleoenvironments in southeastern North Carolina using Ostracoda. In: 2011 GSA Annual Meeting.

Peltier, W.R., 2004. Global glacial isostasy and the surface of the ice-age Earth: The ICE-5G (VM2) model and GRACE. Annu. Rev. Earth Planet. Sci. 32, 111-149.

Pollard, D., DeConto, R.M., 2009. Modelling West Antarctic ice sheet growth and collapse through the past five million years. Nature 458, 329-332.

Potter, E.K., Lambeck, K., 2003. Reconciliation of sea-level observations in the Western North Atlantic during the last glacial cycle. Earth Planet. Sci. Lett. 217 (1), 171-181.

Raymo, M.E., Mitrovica, J.X., O’Leary, M.J., DeConto, R.M., Hearty, P.J., 2011. Departures from eustasy in Pliocene sea-level records. Nat. Geosci. 4, 328-332.

Richards, H.G., 1963. Geology of the Coastal Plain of North Carolina. The American Philosophical Society. New Series.

Roberts, D.L., Karkanas, P., Jacobs, Z., Marean, C.W., Roberts, R.G., 2012. Melting ice sheets $400,000 \mathrm{yr}$ ago raised sea level by $13 \mathrm{~m}$ : Past analogue for future trends. Earth Planet. Sci. Lett. 357, 226-237.

Rowley, D.B., Forte, A.M., Moucha, R., Mitrovica, J.X., Simmons, N.A., Grand, S.P., 2013. Dynamic topography change of the Eastern United States since 3 million years ago. Science 340, 1560-1563.

Sandiford, M., 2007. The tilting continent: a new constraint on the dynamic topographic field from Australia. Earth Planet. Sci. Lett. 261, 152-163.

Soller, D.R., 1988. Geology and tectonic history of the lower Cape Fear River valley, southeastern North Carolina. U.S. Geological Survey professional paper (No. 1466-A).

Spasojević, S., Gurnis, M., 2012. Sea level and vertical motion of continents from dynamic earth models since the Late Cretaceous. Am. Assoc. Pet. Geol. Bull. 96, 2037-2064.

Tedford, R.H., Harington, C.R., 2003. An Arctic mammal fauna from the early Pliocene of North America. Nature 425, 388-390.

Trenhaile, A.S., 2002. Modeling the development of marine terraces on tectonically mobile rock coasts. Mar. Geol. 185 (3), 341-361.

Ward, L.W., Bailey, R.H., Carter, J.G., 1991. Pliocene and early Pleistocene stratigraphy, depositional history, and molluscan paleobiogeography of the coastal plain. In: Horton Jr., J.W., Zullo, V.A. (Eds.), The Geology of the Carolinas, 50th Anniversary Volume. Carolina Geological Society, Raleigh, NC, pp. 274-289.

Winker, C.D., Howard, J.D., 1977. Correlation of tectonically deformed shorelines on the southern Atlantic coastal plain. Geology 5, 123-127. 